\title{
Associated Factors That Hindering Good Governance in Land Administration: The Case of Shashogo Woreda Municipality, Hadiya Zone, Southern Ethiopia
}

\author{
Ageze Chufamo Gobena \\ Senior Lecturer and Researcher \\ Department of Civic \& Ethical Studies at Wachemo University, Ethiopia
}

\begin{abstract}
The main purpose of this research was to assess the Associated factors that hindering Good governance in land administration: The case of Shashogo woreda Municipality, Hadiya Zone, Southern Ethiopia. The specific objectives of this study were. Appraise the level of the openness of land information to residence of town; determine factors affecting good governance in land administration process at Bonosha Municipality. Researcher was employed a cross-sectional study design. Questionnaires, focused-group discussions, structured or semi-structured interviews, which are used as crucial data collection instruments. 384 households were sample size of this study. Questionnaire data was distributed for this sample population. Furthermore, poor governance in municipality land administration process. Constraints in institutional capacity such as human resource issueslack of skilled man power and low level of education, lack of training opportunities, low level of experience.
\end{abstract}

Keywords: Factors, Good governance, Land management and Municipality

DOI: $10.7176 / \mathrm{JRDM} / 64-01$

Publication date: April $30^{\text {th }} 2020$

\section{INTRODUCTION}

Ethiopia is one of the African countries, which has dedicated itself for the idea and practice of good governance in the belief that it is vital to socio-economic and political development. It has introduced federal decentralized system governance which is said important to enhance the effectiveness, responsiveness, accountability and transparency of the state in the delivery of basic services. As result of the post-1991 political order, Ethiopia has empowered the various nations, nationalities and peoples at the levels of national, regional and local governments (Gebreslassie, 2012: 1). Based on the FDRE constitution of 1995, Ethiopia implements a decentralized system of administration. This has lead to the creation of the regional states with different governmental levels which are empowered with considerable autonomy allowing independent decision-making power. The promotion of the self- administration is also defined along with good governance delivery simultaneously. In fact, the new political imitative of federal decentralization that unfolded since the early 1990s can be said one of the most significant changes in the history of the nation. It has, after all, shifted the earlier centrally established tough unitary tradition in favour of right to self-administration by the different nations, nationalities and peoples of Ethiopia. The initiation of decentralization was also aimed as part of broad based efforts to improve effectiveness of the state public service deliveries to advance democratization process (Tsegaye, 2004: 4; ECGP, 2009:7).

However, it can be argued that various factors affect the good governance at national as well as regional levels of government. This particularly appears acute in the area this study is concerned with. It can be argued that there is a gap between theory and practice in the realization and sustaining of the idea of good governance. This is clearly a contradiction to what is defined in the constitution and other basic law documents. The indicators of poor governance such as the lack of responsiveness, transparency and corruption, institutional capacity constraints - human resource issues such as lack of skilled and trained manpower etc could be often mentioned to be barrier for good land administration (Gebreslassie, 2012: 2-5). As Besley and Ghatak (2005:5) have argued, particularly, corruption is a very real problem in many areas of public sector around the world including Ethiopia.

In Ethiopia urban land administration and delivery processes have been problematic due to the absence of good governance such as lack of transparency, corruption. Similarly, urban land supply was not demand responded. In the same manner, land provision and efficient land use administration are essential urban services, critical to poverty reduction processes in Ethiopia's urban centres. However, it is possible to observe in the municipality sectors that there are many problems in land use management that have a significant impact on the dynamics of the government system as a whole. Among others, lack of clarity in the legal framework governing urban land use, including the powers and functions assigned to various levels of government and lack of clear criteria and enforcement mechanisms for expropriation and compensation of privately occupied land are basic. These have prevented municipalities from effectively planning for land development within their jurisdictions. Moreover, institutional weaknesses in land management such as land survey and cadastral systems prevent 
government of municipalities from optimally extracting land and property rates (SDPRP, 2002:21). There was no research conducted in the study area. This was believed as gap of this study.

Therefore, the objective of this study is to assess the challenges of good governance in urban land administration process, which is found at of shashogo woreda municipality,

\subsection{Objectives}

The general objective of the study is assessing the associated factors that hindering good governance in land administration: the case of shashogo woreda municipality, Hadiya Zone, SNNPR

Based on this, the specific objectives of the study are the following: To

- Appraise the level of the openness of land information to residence of town

- Determine factors affecting good governance in land administration process at Bonosha Municipality.

\subsection{Conceptual Frame Work of the Study}

The proposed conceptual framework builds on existing evidence that addresses factors that affect good governance in land administration. It shows how dependent and independent variables are related each other. The following is a brief illustration of the relationship between independent and dependent variables.

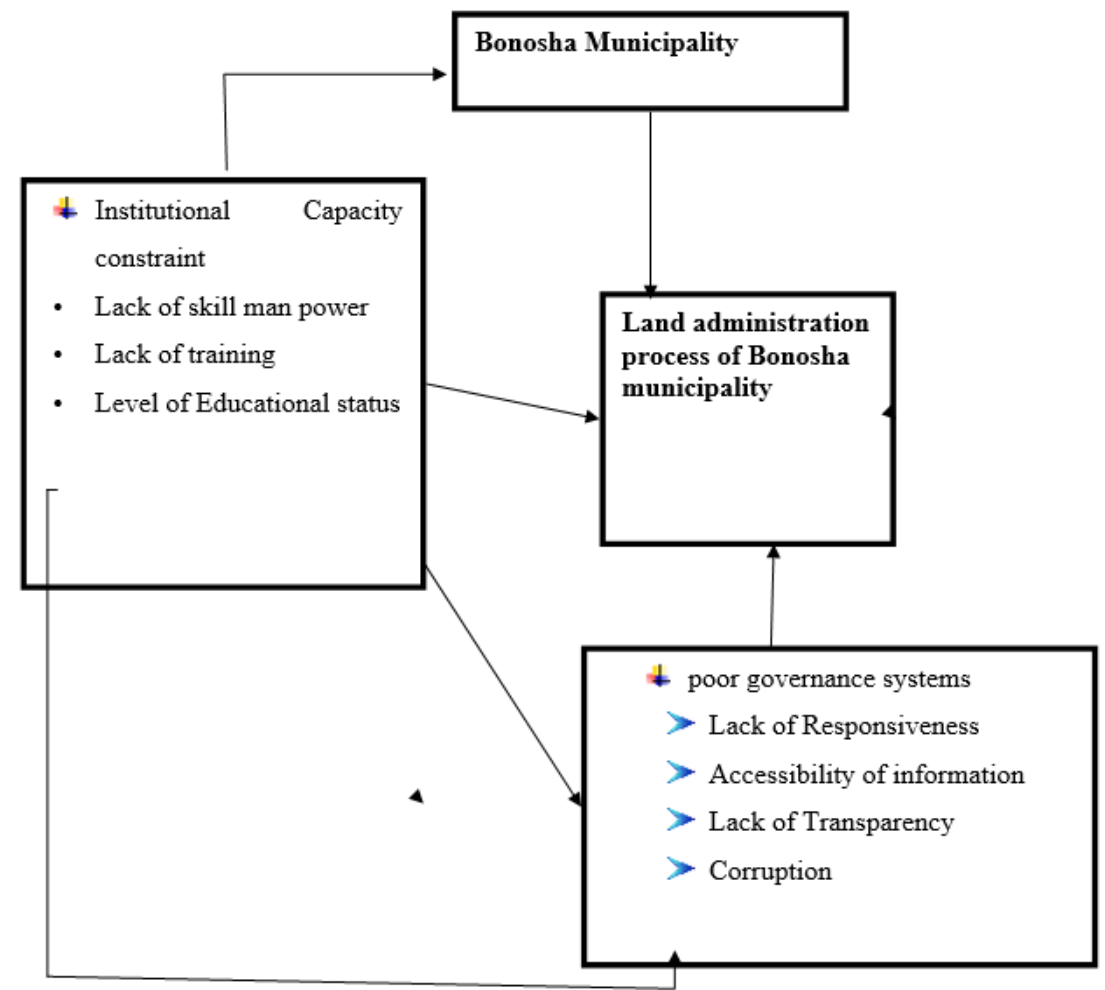

Figure 1: The relationship between independent and dependent variables.

Source: Authors assumption as developed based on literature review

\section{Methodology and Method of Data Collection}

\subsection{Description of the Study Area and Sites of Data Collection}

This study was conducted in Bonosha town which is located in $224 \mathrm{~km}$ away from Addis Ababa, the capital of Ethiopia. Bonosha town is administrative centre of the shashogo woreda. It is bordered by the Kembata Tembaro Zone in the south, Lemo woreda in the west, Anlemo woreda in the north west, Silti zone in the northeast and Alaba Special Woreda in the southeast. According to Shashogo Woreda Revenue Statistical Abstract/SWRSA (2013), 8200 are Bonosha town households .Administratively, the Woreda consists of two municipalities namely; Bonosha and Doisha, and 34 rural kebeles. Of these, Bonosha municipality was selected as centre of study area. 


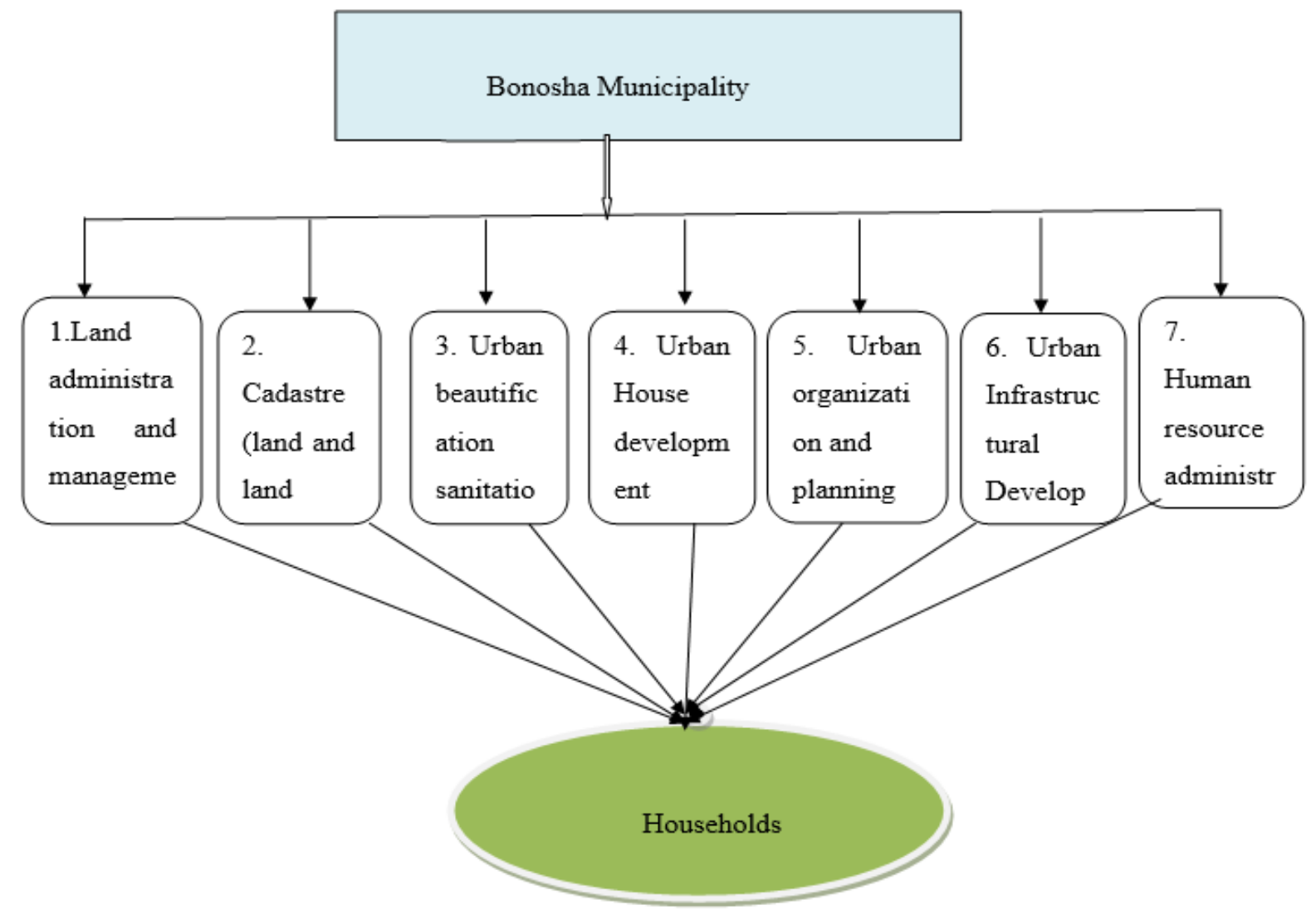

Figure 2: Organizational structure of Bonosha Municipality

Sources: Thesis writer's assumption as developed based on field trip in 2013

\subsection{Study Approach and Target Population}

The researcher was used both quantitative and qualitative data collection approaches. The target population for data collection is comprised from category of public that includes officials, service providers and ordinary, that is, service seeking people /households. Therefore, it is examined the public representatives, office holders, and residents from urban taken into consideration.

\subsection{Inclusion and Exclusion criterion}

\subsubsection{Inclusive criteria}

$\checkmark$ Permanent resident of the Bonosha town (at least those who have lived for 1 years)

\subsubsection{Exclusive criteria}

$\checkmark$ Those people who were severely ill or unable to respond and minority below the age of 18 years during the time of data collection were not approached.

\subsection{Sample size determination and sampling technique}

\section{4.1. Sample size determination}

Sample size (n) required for the study was calculated using single population proportion formula

$$
n=\frac{\left(Z \frac{\alpha}{2}\right)^{2} P(1-p)}{d^{2}}
$$

Hence,

$\mathbf{n}$ - is the minimum sample size required

$\mathbf{Z \alpha} / \mathbf{2}$ - critical value for normal distribution at $95 \%$ confidence interval $=1.96$ ( $\mathrm{Z}$ value at alpha $=0.05$ )

$\mathrm{P}=50 \%$ was taken there was no any study round

$\mathrm{d}=5 \%$ margin of error 


$$
n=\frac{\left(Z \frac{\alpha}{2}\right)^{2} P(1-p)}{d^{2}} \frac{(1.96)^{2}(o .5)(0.5)}{(0.05)^{2}}
$$

$n=384$

\subsubsection{Sampling Procedure}

A study participant was selected by using systematic random sampling technique until the required sample size fulfilled. The calculated sample was proportionally allocated to study Town. Then sampling interval ' $\mathrm{k}$ ' was calculated dividing the total numbers of households by required sample size. The first household was taken randomly and every $\mathrm{k}^{\text {th }}$ household was identified until the required sample size filled..

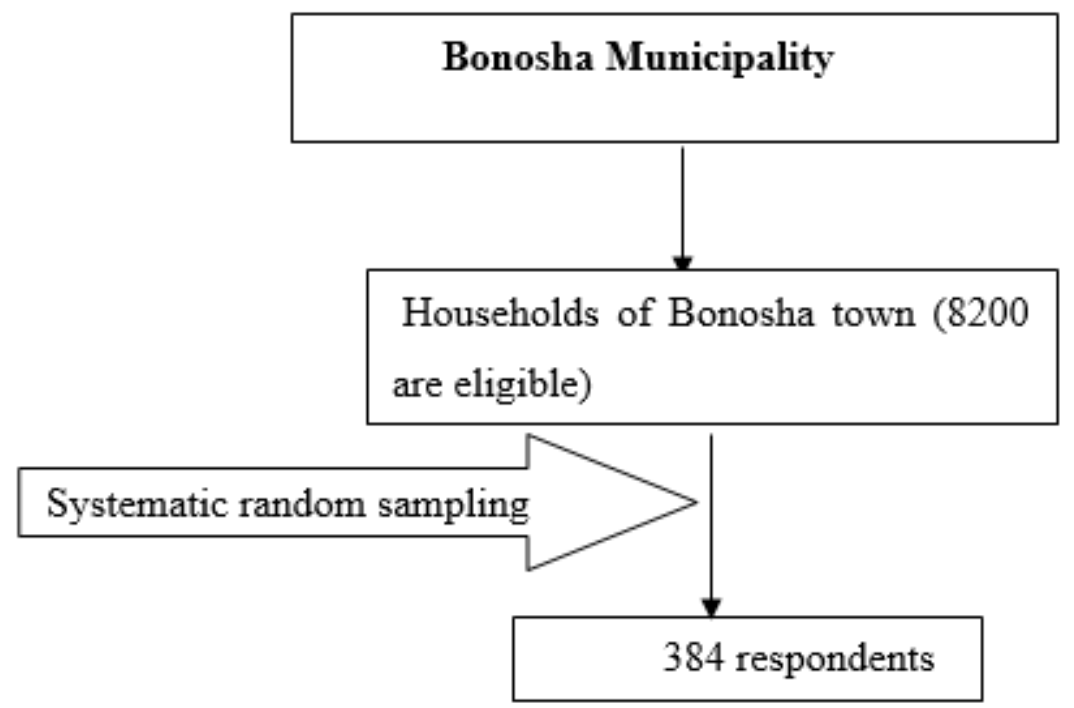

Figure 3.The sampling procedure to select study subjects for the study on the challenge of good governance in land administration of Bonosha Municipality with reference to Shashogo woreda, Hadiya Zone in 2013.

Sources: Thesis writer's assumption as developed based on field trip

\subsection{Study Design and Sampling Techniques}

Cross sectional study was conducted to assess challenges of good governance in land administration of Bonosha municipality .A systematic random sampling technique was employed for households whereas the study area and the municipality were selected using purposive sampling techniques

\subsection{Study Variable:}

3.6.1. Dependent variable:

$\checkmark$ Good governance in land management at Bonosha municipality

\subsubsection{Independent variables:}

> Poor governance: Responsiveness, Transparency, information accessibility and Corruption

$>$ Institutional capacity constraint ;

- Level of Educational status

- Lack of training

- Lack of skill man power

\subsection{Sources of Data Collection}

For this study the investigator employed both secondary and primary sources of data.

\subsection{The Nature of Data Collection Tools}

The following data collection tools were employed i.e., questionnaire, in depth interview, key informant interviews and focus group discussion.

\subsection{Data Analysis}

Data was enter to SPSS 20.0 statistical software to edit, clean for inconsistencies and missing values and finally 
to analyze. Different frequency tables and descriptive summaries was used to describe the study variables. Qualitative data such as interview and focal group discussion was analyzed by transcribing informant's ideas and views through narrations, descriptions and discussions to help capture aspects of the research that could not be done through the quantitative method. In all statistical analysis, confidence level was held at $95 \%$ and P-value is $<0.05$ (at $5 \%$ level of significance was considered as significant). Moreover, they were important to cross-check information obtained based on individual or personal interviews and questionnaire administration in order to find out authentic evidence out of data triangulation.

\section{RESULTS AND DISCUSSION}

4.1 Socio-Demographic characteristics of the Respondents

The figure below shows the sex of the respondents who were surveyed in this Study. Of the 384 participants were sampled. From the total respondents, $283(73.7 \%)$ were male while the rest, that is, $101(26.3 \%)$ female respondents. These findings show that the majority who were surveyed in this Study was male and the others were female. This result is seen in following figure-4

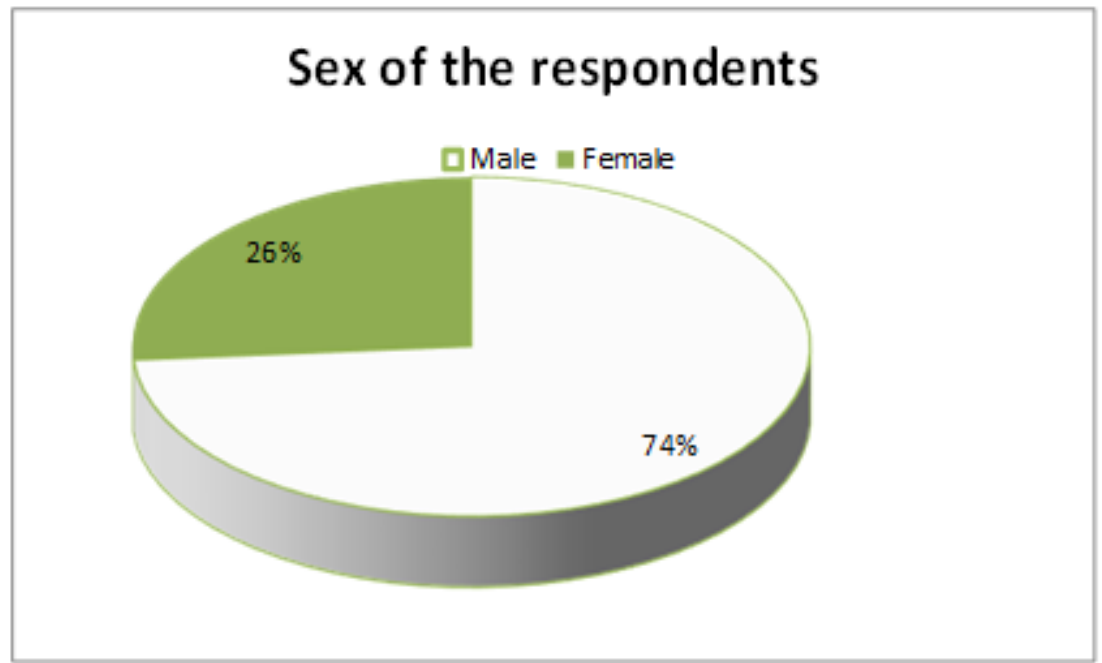

Figure 4: sex of respondents

Source: author in 2013

On the topic of the income survey of the respondents, $89(23.2 \%)$ had an income range between less than500 Birr per month, 85(22.1\%) of respondents had an income range b/n 501-1000ETB, 74(19.3\%) had between 1001-1500ETB, 70(18.2\%) of respondents was b/n 1501-2000ETB and the remaining $66(17.2 \%)$ of participants had above 2000ETB. This illustrated that the majority of respondents' monthly income is less than 500ETB. This data is revealed as follows in the figure 5.

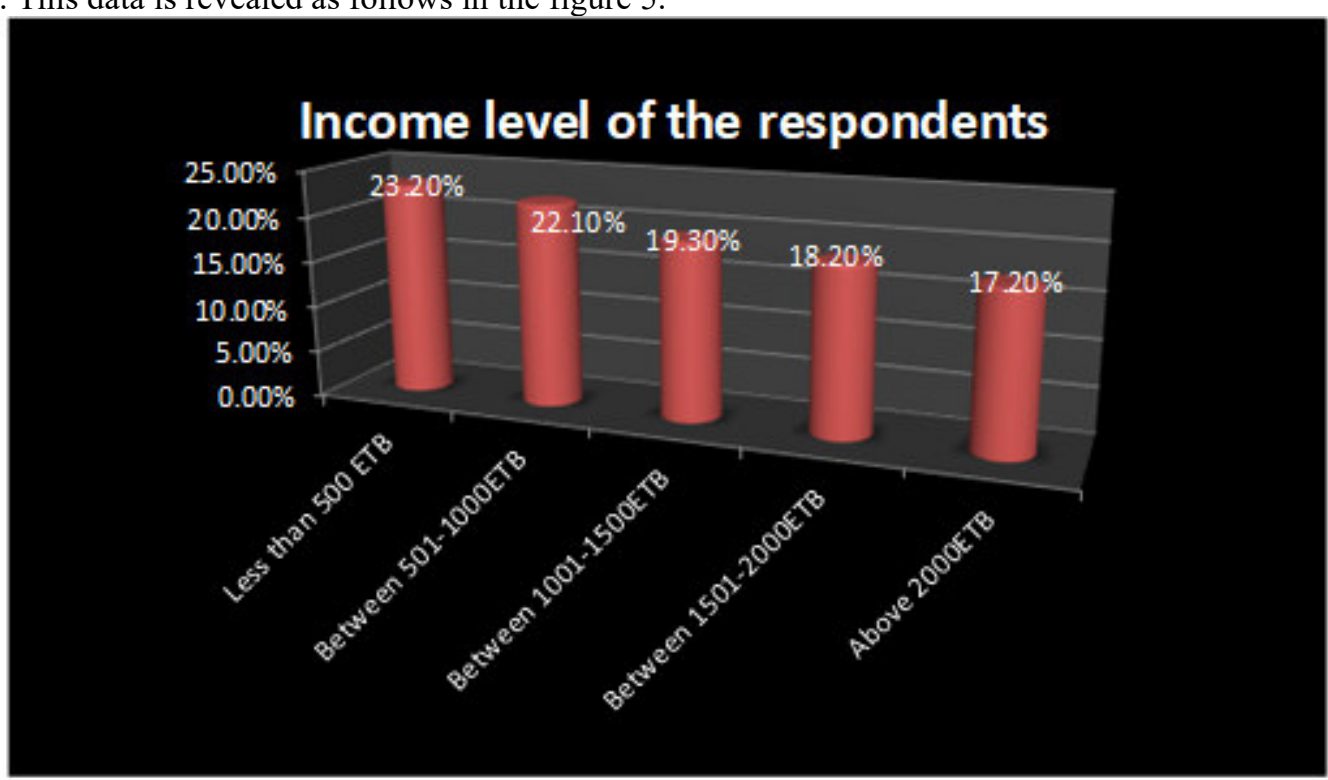

Figure 5: income level of the respondents

Source: Author in 2013 
Respondents also asked about their source of source of revenue. From the total $384(100 \%)$ study population, large number of the respondents $125(32.6 \%)$ were traders. Whereas the remaining respondents $112(29.2 \%), 74(19.3 \%), 50(13.0 \%), 18(4.7 \%), 5(1.3 \%)$ were Governmental employee, Farmer, day labourer, NGO workers and Housewife respectively. This result is shown as below in figure-6

\section{Occupational status of the respondents}

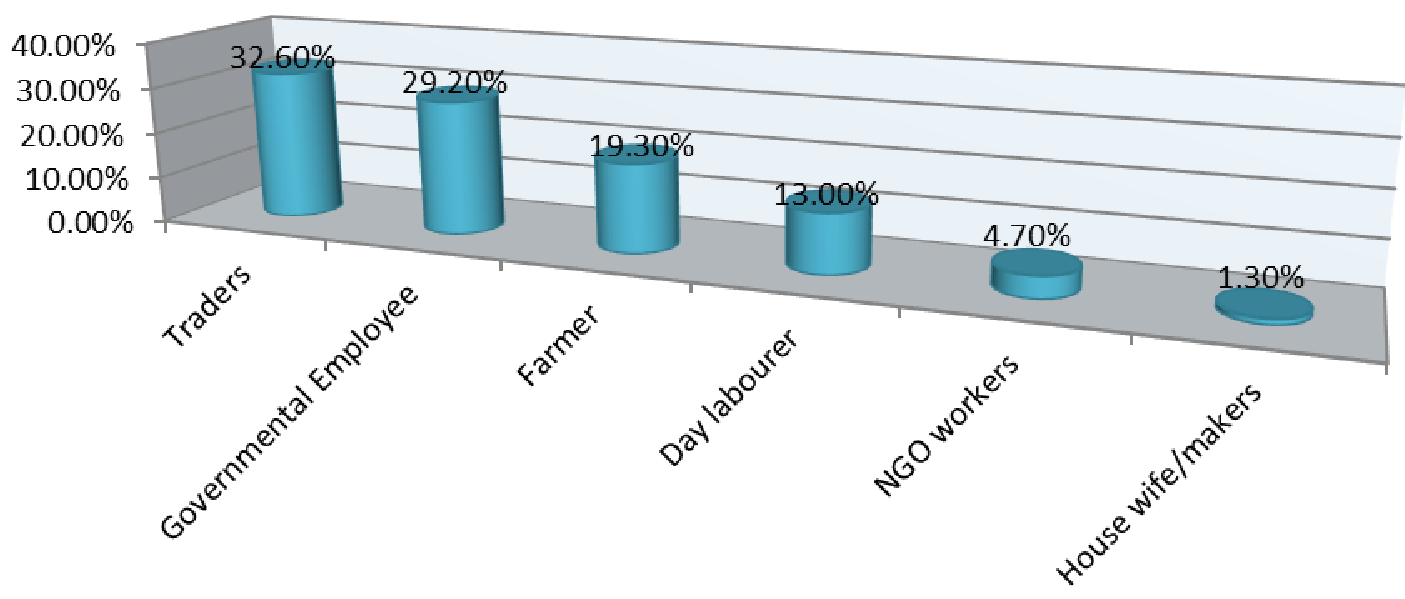

Figure 6: occupational status of the respondents

Source: author in 2013

\subsection{Access of Housing and land administration process in Bonosha town}

Table 1: Access of housing, land administration and its related issues of Bonosha residents, 2013.

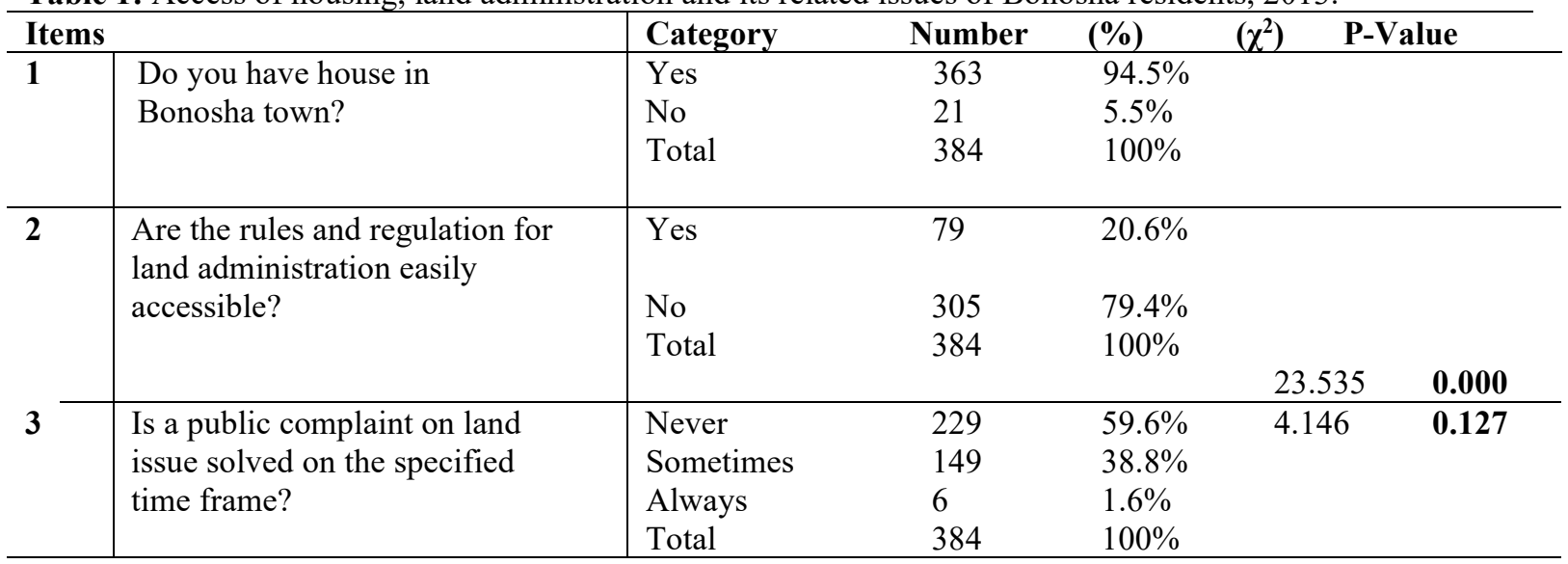

The data in Table 1 of item 1 reflects the percentage of respondents that have house and not in Bonosha town. Almost (94. 5\%) of respondents have house in the town, while only about $(5.5 \%)$ respondents do not have housing access in the town. In the meantime as shown in item 2 of the table, 79 (20. 6) percent of the respondents agree with accessibility of rules and regulations of the land administration. About 305 or (79.4\%) of respondents however do not agree on that rules and regulations of the land administration are easily accessible. One of the limitations in this regard is the absence of adequate and open discussion forums between residents of the town and the concerned body of the municipality creating awareness on the issue. Statistical analysis also indicated there was significant association $\left(\chi^{2}=23.535, \mathrm{p}=\mathbf{0 . 0 0 0}\right)$ between challenges of good governance and land administration, which is not easily obtainable in terms of its rules and regulations. The present finding goes to agree with literature, which states that there are many land use management issues that have a significant impact on the dynamics of the government system as a whole. Among these, lack of clarity in the legal framework governing urban land use, including the powers and functions assigned to various levels of government and lack of clear criteria and enforcement mechanisms for expropriation and compensation of privately occupied land are basic. These have prevented municipalities from effectively planning for land 
development within their jurisdictions. Moreover, institutional weaknesses in land management such as land survey and cadastral systems prevent government of municipalities from optimally extracting land and property rates (SDPRP, 2002:21). On public compliant on land issues (item 3 of the table) about 229 (59.6\%) of respondents of the town as customer have reported that the public complaint on land issue is never solved on the specified period of time, while about $149(38.8 \%)$ responded on sometimes basis and $6(1.6 \%)$ on always basis.

Besides, the information obtained from the above data tally was cross-checked with information from the participants of focus group discussion and interviews. Both ways of gotten information have suggested in fact for non-existence of transparency in the allocation and distribution of land by the municipality. In the main, the problem is centred in the lack of an open public forum for discussion about land allocation and distribution. In the opposite, the authorities of the municipality administration are presupposed to use the land for rent-seeking benefits by selling it illegally for individuals. As one informant told me, land selling negotiation takes place involving woreda or municipality officials with buyers like any commodity in the normal markets centres.

\subsection{Transparency level of municipality Officials on land related issues}

Respondents were asked about governance related question in land administration process like municipality officials are transparent? From the total 384 respondents, the majority $282(73.4 \%)$ are responded that the employee and officials not to be at all transparent, $93(24.2 \%)$ of them are said that a majority of the employees/officials are not transparent, whereas the remaining $9((2.3 \%)$ of the respondents are transparent. The statistical analysis of the data showed for the presence of significant association $\left(\chi^{2}=19.072, \mathrm{P}=0.000\right)$ between municipal land management process and lack of transparency. As a result, it is not surprising that the case does come to agree with the literature definition of good governance which states a clear and predictable legal framework, transparency and information on the management of national affairs at all levels" Sebudubudu (UNDP, 1997; 2010). This result is revealed as below in figure $\mathbf{- 7}$

\section{Transparency level of munacipality officials on land related questions}

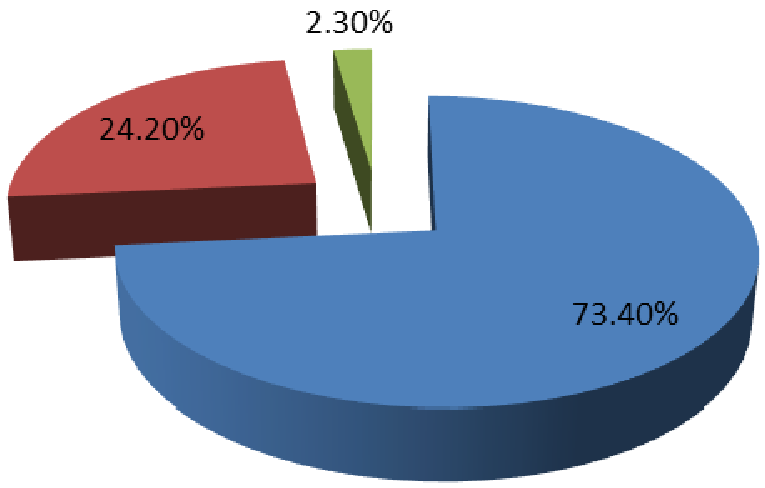

all are not transparent

Majority are not transparent

nome are transparent

\section{Figure 7: Transparency}

Source: Author in 2013

\subsubsection{The level of the openness/ accessibility of land related information to the residents of Town}

Respondents of this study were asked about openness and accessibility of land related questions i.e. does your municipality carry out open discussion with people on issues of land administration and clarity rule and regulation of land? As data revealed that, the majority of the respondents $340(88.5 \%)$ were said that Never, 44 (11.5) were said that sometimes. In agreement with questionnaire, the information based on interviews and focused groups discussion respondents asked about prevalence of corruption; they said that there is high degree of corruption in our municipality. The data indicated as in the following figure- 8 


\section{Openness/accessibility}

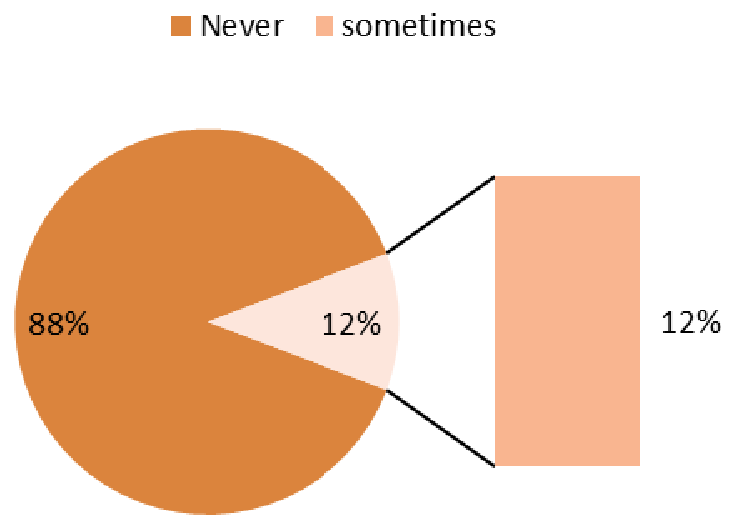

Figure 8: openness/ accessibility of land related information Source: Author in 2013

\subsection{Institutional capacity constraint}

Table 2: The Profile of Employee0s of Bonosha Municipality

\begin{tabular}{|c|c|c|c|c|}
\hline № & Indicator & Category & Number & $\%$ \\
\hline 1 & Sex & $\begin{array}{l}\text { Male } \\
\text { Female } \\
\text { Total }\end{array}$ & $\begin{array}{l}11 \\
2 \\
13 \\
\end{array}$ & $\begin{array}{l}84.6 \% \\
15.4 \% \\
100 \% \\
\end{array}$ \\
\hline 2 & Educational level & $\begin{array}{l}\text { 10/12 complete } \\
\text { Diploma } \\
\text { First degree } \\
\text { Masters and above } \\
\text { Total }\end{array}$ & $\begin{array}{l}5 \\
6 \\
2 \\
- \\
13 \\
\end{array}$ & $\begin{array}{l}38.4 \% \\
46.2 \% \\
15.4 \% \\
- \\
100 \% \\
\end{array}$ \\
\hline 3 & Experience & $\begin{array}{l}\text { Below } 1 \text { years } \\
1-2 \text { years } \\
2-4 \\
4-5 \\
5 \text { and above } \\
\text { Total }\end{array}$ & $\begin{array}{l}2 \\
5 \\
4 \\
1 \\
1 \\
13\end{array}$ & $\begin{array}{l}15.4 \% \\
38.4 \% \\
30.8 \% \\
7.7 \% \\
7.7 \% \\
100 \%\end{array}$ \\
\hline
\end{tabular}

Source: Bonosha Municipality Office (2013)

As it can be observed from the data shown in Table 2, out of the 13 Bonosha Municipality employees $11(84.6 \%)$ are male, while $2(15.4 \%)$ are female employees. Regarding educational level of employees, about 5 $(38.8 \%)$ employees are either $10^{\text {th }}$ or $12^{\text {th }}$ complete, about $6(46.2 \%)$ diploma holder, while the remaining 2 $(15.4 \%)$ are degree holders .The majority $(84.6 \%)$ of employees therefore lies in between grade 10 and /12 and diploma. For a municipality with standard of Bonosha town it can be said that the existence of 2 degree holders is not sufficient for good land management.

Fulfilment with the experience of employees is also minimal. It is observable that from the table that out of 13 employees $2(15.4 \%)$ of belong to less than one year working experience, while $5(38.4 \%)$ of them are within a range of 1-2 years experience and $4(30.8 \%)$ of employees are within the range of $2-4$ years experience. About $1(7.7 \%)$ of employees belong to experience ranging from 4 to 5 year and only $1(7.7 \%)$ has experience above five years. The result of data shows that the largest percentage $(92.3 \%)$ of employees are with less than five years working experience. So, above findings are highly associated with good land management process of municipality.

\section{Summary of Housing and Land Administration Finding}

- The data shows that the majority respondents or 94 percent are house owner. Still, they are not fully content 
with the service provision or implementation of government rules and regulations in this regard. The major sources of public complaints are said to stem of good governance, that is, from setback of transparency, responsiveness, corruption and open forums for public consultation.

- In terms of institutional capacity, the constraints of Bonosha town include insufficient number of employees, skilled or specialized labor and low-level educational personnel. Moreover, there is no attempt to upgrade personnel capacity through training and further education.

\subsubsection{Recommendation}

Based on the findings researcher recommends the following challenges to be concerns of improvement.

- They must emphasize on open government management in order to resolve local affairs. They should be responsive, transparent and open to public judgment by establishing offices that could receive and settle people complaints. They should have commitment to bring irresponsible workers and officials to due process of law for every criminal act against the public interest.

- The municipality management together with woreda administrators should empower the capacity of the land administration staffs by providing short and long-term trainings to reduce related issues. The result of Table 1 of item 2 indicates that $79.4 \%$ of respondents agree that they were not able to obtain easily the rules and regulations of the land administration. The result of Table 1 of item 3 indicates that $59.6 \%$ of customary respondents reported that the public complaint on land issues have no proper responses.

- This can be achieved by empowering the capacity of municipality officials through long and short-range trainings.

\section{Reference}

$>$ Besley. T and M .Ghatak, 2005, 'Reforming Public Service Delivery, London School of Economics', London, UK, African Journal ECONOMIES.Vol.16 pp127-156

$>$ ECGP.,2009, 'Federal Democratic Republic of Ethiopia Country Governance Profile' ,African Development Bank and Fund.

$>$ Gebreslassie Kiros Hailu , 2012 , 'Challenges of good governance in local government: the case of saesietsaedanbaWoreda,Tigria region', Arba MinchUniversity,Ethiopia ,International e-Journal. Vol. 2 (3) pp 2231-4245.

$>$ Sebudubudu David, 2010, 'The impact of good governance on development and poverty in Africa: Botswana - A relatively successful African initiative' in African Journal of Political Science and International Relation.Vol.4(7) pp249-262.

$>$ Tsegaye Regassa, 2004. 'State Constitutions in Ethiopian Civil Service College, Addis Ababa, Ethiopia.'

$>$ UNDP, 1997, 'Good governance - and sustainable human development.' 